Maurice A. Deane School of Law at Hofstra University Scholarly Commons at Hofstra Law

Hofstra Law Faculty Scholarship

$10-2013$

\title{
Kiobel and The Surprising Death of Universal Jurisdiction Under The Alien Tort Statute
}

Julian G. Ku

Maurice A. Deane School of Law at Hofstra University

Follow this and additional works at: https://scholarlycommons.law.hofstra.edu/faculty_scholarship

\section{Recommended Citation}

Julian G. Ku, Kiobel and The Surprising Death of Universal Jurisdiction Under The Alien Tort Statute, 107 Am. J. Int'1 L. 835 (2013)

Available at: https://scholarlycommons.law.hofstra.edu/faculty_scholarship/738

This Article is brought to you for free and open access by Scholarly Commons at Hofstra Law. It has been accepted for inclusion in Hofstra Law Faculty Scholarship by an authorized administrator of Scholarly Commons at Hofstra Law. For more information, please contact lawcls@hofstra.edu. 


\title{
KIOBEL AND THE SURPRISING DEATH OF UNIVERSAL JURISDICTION UNDER THE ALIEN TORT STATUTE
}

\author{
By Julian G. Ku*
}

The U.S. Supreme Court's decision in Kiobel v. Royal Dutch Petroleum Co. ${ }^{1}$ has not ended future debate about the scope and impact of the Alien Tort Statute (ATS). ${ }^{2}$ But the Kiobel Court did resolve at least one issue with surprising unanimity: both the opinion for the Court by Chief Justice John Roberts and the main concurring opinion by Justice Stephen Breyer refused to interpret the ATS as authorizing universal jurisdiction. All nine justices rejected decades of lower-court precedent and widespread scholarly opinion when they held that the ATS excluded cases involving purely extraterritorial conduct, even if the alleged conduct constituted acts that are universally proscribed under international law.

In this short essay, I argue that the surprising death of universal jurisdiction reflects the triumph of the "separation of powers" critique of the ATS, which casts a skeptical eye on giving federal courts an independent role in the administration of both ATS lawsuits and cases involving international law more generally. I argue that this separation of powers critique of the ATS, which has found relatively little academic support, is a crucial reason why the Court unanimously rejected universal jurisdiction in Kiobeland why the Court may further restrict the ATS in future cases.

\section{Universal Jurisdiction and the ATS}

When a state seeks to exercise jurisdiction outside of its territory, international law generally requires the state to show some connection to its territory, nationality, or national security interests. These limitations flow from fundamental international legal principles of sovereign equality and noninterference in the domestic affairs of sovereign states. ${ }^{3}$

But international law has long recognized an exception to this framework for a certain set of serious crimes: universal jurisdiction. Under this principle, any nation has the right to exercise prescriptive and adjudicative jurisdiction over certain crimes, irrespective of any connection between that crime and its territory. Historically, states invoked universal jurisdiction to apply their criminal laws to acts like piracy, but, in the modern era, universal jurisdiction is often justified by the severity and heinousness of the crimes. Hence, states have imposed criminal liability for acts such as torture and genocide, even if those acts had no territorial or other connection to a state. ${ }^{4}$

\footnotetext{
* Professor of Law, John Dewitt Gregory Research Fellow, and Faculty Director of International Programs, Maurice A. Deane School of Law at Hofstra University. The author would like to thank Tatiana Sulovska, Hofstra Law class of 2015, for her outstanding research assistance on this project.

1 Kiobel v. Royal Dutch Petroleum Co., 133 S.Ct. 1659 (2013).

28 U.S.C. $\$ 1350$.

${ }^{3}$ UN Charter Art. 2.

4 See, e.g., 1 RESTATEMENT (THIRD) OF THE FOREIGN RELATIONS LAW OF THE UNITED STATES $\$ 404$ (1987) [hereinafter RESTATEMENT]; M. CHERIF BASSIOUNI, 2 INTERNATIONAL CRIMINAL LAW: MULTILATERAL AND BILATERAL ENFORCEMENT MECHANISMS 169-80 (3d ed. 2008) (discussing the basis for universal jurisdiction over these crimes).
} 
From its revival in 1980, the ATS has frequently been invoked for cases involving purely extraterritorial conduct by foreign nationals and involving allegations that those acts violate "universal" international law standards. In the seminal ATS case, Filártiga v. Peña-Irala, ${ }^{5}$ the U.S. Court of Appeals for the Second Circuit allowed two Paraguayan nationals to bring an ATS lawsuit against a former Paraguayan government official for committing torture in Paraguay. Although the Filártiga court did not invoke universal jurisdiction directly, it relied on the "well-established, universal[]" prohibition of torture under customary international law to support its decision to apply the ATS to the Paraguayan defendant. ${ }^{6}$

Because the Filartiga court justified its extraterritorial reach under the "transitory torts" doctrine (an approach eventually rejected by the Kiobel Court), the first U.S. courts to apply the ATS only indirectly considered the scope or significance of universal jurisdiction. ${ }^{7}$ In Kadic v. Karadzić, the Second Circuit held that international law permitted the imposition of civil liability on natural persons for certain universally proscribed acts under international law. ${ }^{8}$ The Kadic court also cited with approval the Restatement (Third) of the Foreign Relations Law of the United States, which noted that, while universal jurisdiction was typically applied in the criminal context, "international law also permits states to establish appropriate civil remedies" for universally proscribed acts. ${ }^{9}$ This ruling was one of the first times that a U.S. court recognized that at least some ATS cases involve the exercise of universal jurisdiction.

This connection between the ATS and universal jurisdiction became more explicit in 2004 when the Supreme Court decided Sosa v. Alvarez-Machain. ${ }^{10}$ Although the Sosa case arguably did not require the invocation of universal jurisdiction since it involved U.S. government action, the Court made clear that any ATS cause of action must satisfy a rigorous "specific, universal, and obligatory" standard. ${ }^{11}$ The Court highlighted the importance of this standard not only as a way to conform to historical understandings of the ATS's substantive scope but also as a way to satisfy concerns about judicial abuse of ATS powers that could negatively affect U.S. foreign relations.

Additionally, Breyer's concurring opinion in Sosa directly embraced universal jurisdiction as a way to assuage concerns about judicial overreaching based on the ATS, suggesting that limiting ATS claims to universal jurisdiction crimes for which there was widespread international recognition would safeguard international comity. ${ }^{12}$ Citing an amicus brief filed by the European Commission, he noted that nations have, in a narrow set of crimes, reached a "procedural agreement that universal jurisdiction exists to prosecute a subset of that behavior." ${ }^{13}$ When

${ }^{5}$ Filártiga v. Peña-Irala, 630 F.2d 876 (2d Cir. 1980).

${ }^{6} \mathrm{Id}$. at 888.

7 See, e.g., Kadic v. Karadžić, 70 F.3d 232, 236 (2d Cir. 1995) (claim related to atrocities committed in Bosnia by leader of Bosnian Serb forces); In re Estate of Marcos, Human Rights Litig., 25 F.3d 1467, 1475 (9th Cir. 1994) (claim related to torture and wrongful death committed in the Philippines by former Philippine president); Beanal v. Freeport-McMoRan, Inc., 969 F.Supp. 362, 371 (E.D. La. 1997).

${ }^{8}$ Kadic, 70 F.3d at 239.

${ }^{9}$ Id. at 240 (citing RESTATEMENT, supra note $4, \$ 404 \mathrm{cmt}$. b).

${ }^{10}$ Sosa v. Alvarez-Machain, 542 U.S. 692 (2004).

${ }^{11} \mathrm{Id}$. at 732.

${ }^{12}$ Id. at 760 (Breyer, J., concurring) (quoting Marcos, 25 F.3d at 1475).

${ }^{13}$ Id. at 762 (citing Brief of Amicus Curiae the European Commission in Support of Neither Party at $24 \mathrm{n} .54$, Sosa v. Alvarez-Machain, 542 U.S. 692 (2004) (No. 03-339), available at http://documents.law.yale.edu/sites/ default/files/Brief\%20of\%20European\%20Commission\%20to\%20Sosa.pdf). 
such an agreement is reached, concerns about interference in a foreign sovereign's affairs are lessened, if not eliminated. Breyer's concurrence was an important judicial recognition of the connection between the ATS and universal jurisdiction. Scholars also hailed his opinion as evidence of an emerging norm of universal jurisdiction in the civil as well as criminal sphere. ${ }^{14}$

The significance of universal jurisdiction in the ATS became even more apparent in the Kiobel case. In defending the extraterritorial application of the ATS, the petitioner (and numerous amici) pointed out that almost all ATS claims (including those alleged in Kiobel) satisfied international law standards for universal jurisdiction. ${ }^{15}$ Universal jurisdiction thus became a key element in the defense of the ATS against charges of American judicial overreach.

\section{Kiobel and Universal Jurisdiction}

Despite its prominence in Sosa and subsequent academic support, both the Roberts majority opinion and the Breyer concurring opinion rejected a universal jurisdiction reading of the ATS. Because the Roberts opinion noted that the "presumption against extraterritoriality" applies to the ATS, ${ }^{16}$ he had to consider the argument that the presumption was unnecessary since the statute seemed limited to universal jurisdiction causes of action. Citing the Torture Victim Protection Act, ${ }^{17}$ he observed that identifying a universal norm is "only the beginning of defining a cause of action" and that providing detailed definitions, specifying who may be liable, establishing a statute of limitations, and creating a rule of exhaustion "carr $[y]$. . . significant foreign policy implications." 18 Later on in the opinion, Roberts noted that there is no historical or legislative history to support making the United States the "custos morum of the whole world." ${ }^{19}$ In other words, he saw no basis for reading the ATS to authorize U.S. courts to exercise universal jurisdiction.

Given Roberts's reliance on the presumption against extraterritoriality, it is not surprising that he gave universal jurisdiction little consideration. But given Breyer's endorsement of universal jurisdiction in his concurring opinion in Sosa, it is striking that Breyer's concurring opinion in Kiobel carefully avoided basing its claim on universal jurisdiction. Indeed, his reluctance to embrace universal jurisdiction under the ATS is even more surprising because Breyer held that the proper source for defining the extraterritorial scope of the ATS is "international jurisdictional norms." ${ }^{20}$ As he then explained, the traditional bases for prescriptive jurisdiction

\footnotetext{
${ }^{14}$ See, e.g., Donald Francis Donovan \& Anthea Roberts, The Emerging Recognition of Universal Civil Jurisdiction, 100 AJIL 142, 163 (2006); Pierre N. Leval, Distant Genocides, 38 YALE J. INT'L L. 231 (2013).

${ }^{15}$ See, e.g., Petitioners' Supplemental Opening Brief, Kiobel v. Royal Dutch Petroleum Co., 133 S.Ct. 1659 (2013) (No. 10-1491); Supplemental Brief of Yale Law School Center for Global Legal Challenges as Amicus Curiae in Support of Petitioners, Kiobel v. Royal Dutch Petroleum Co., 133 S.Ct. 1659 (2013) (No. 10-1491); Supplemental Brief of Amici Curiae International Law Scholars in Support of Petitioners, Kiobel v. Royal Dutch Petroleum Co., 133 S.Ct. 1659 (2013) (No. 10-1491). Briefs related to Kiobel are available online at http://cja.org/ section.php?id=509.

${ }^{16}$ Kiobel v. Royal Dutch Petroleum Co., 133 S.Ct. 1659, 1665 (2013).

${ }^{17}$ Pub. L. 102-256, 106 Stat. 73 (1992) (codified at 28 U.S.C. $\$ 1350$ note).

${ }^{18}$ Kiobel, 133 S.Ct. at 1665.

${ }^{19} \mathrm{Id}$. at 1668 (quoting United States v. La Jeune Eugenie, 26 F.Cas. 832, 847 (C.C.D. Mass. 1822) (No. $15,551))$.

${ }^{20} \mathrm{Id}$. at 1673 (Breyer, J., concurring) ("And just as we have looked to established international substantive norms to help determine the statute's substantive reach, so we should look to international jurisdictional norms to help determine the stature's jurisdictional scope" (citation omitted).).
} 
under international law are (1) territory; (2) nationality; (3) conduct that has an effect on territory; (4) foreign conduct that is directed against the security of the state or against a limited class of other state interests; and (5) certain crimes of universal concern. ${ }^{21}$

Curiously, he then proceeded to rely only on the first four bases of jurisdiction. In his view, the ATS allows jurisdiction where conduct occurs on U.S. territory, where the defendant is a U.S. national, or where the defendant's conduct "substantially and adversely affects an important American national interest." 22 Without any explanation, he excluded ATS jurisdiction based on universally proscribed conduct from his discussion. Instead, he would "interpret the statute as providing jurisdiction only where distinct American interests are at issue." 23

Breyer concentrated the rest of his opinion on why preventing torturers from gaining safe harbor in the United States is a distinct American interest. Citing numerous authorities that support the punishment of pirates found within a nation's jurisdiction, he argued that there is no extraterritorial bar to using the ATS to compensate victims of "piracy and its modern-day equivalents" who come within U.S. territorial jurisdiction. But Breyer refused to read the ATS to reach as far as the international law of universal jurisdiction would permit, despite the urgings of both petitioners and their amici. Thus, Breyer abandoned his earlier embrace of a universal jurisdiction reading of the ATS in Sosa. While the European Commission brief in Kiobel argued that universal civil jurisdiction was now accepted under international law, ${ }^{24}$ Breyer refused to read the ATS to embrace this purported international trend. Though he claimed that international law principles should define the ATS, he then excluded (without any explanation) universal jurisdiction from the international law principles incorporated into the ATS.

Neither Roberts nor Breyer offers any historical evidence to support their rejection of a universal jurisdiction reading of the ATS. Since the text of the ATS is famously elusive, it is not surprising that the text also fails to explain the more limited reading that both justices embrace. In the next and final section, I will argue that this aspect of both opinions is best explained as motivated by the separation of powers concerns raised by universal jurisdiction.

\section{The Separation of Powers Critique of the ATS}

Since the ATS was revived in 1980, it has been hailed in the academic community as an important milestone in the development of international law and the vindication of victims'

${ }^{21} I d$. (citing RESTATEMENT, supra note 4, $\$ \$ 402,404$ ).

22 Id. at 1674 .

${ }^{23}$ Id. (emphasis added).

${ }^{24}$ Supplemental Brief of the European Commission on Behalf of the European Union in Support of Neither Party at 13-26, Kiobel v. Royal Durch Petroleum Co., 133 S.Ct. 1659 (2013) (No. 10-1491) (arguing that universal civil jurisdiction under the ATS conforms to international law principles of jurisdiction). Reasons exist to doubt this claim, however, since most of the examples cired by the European Commission involve civil recovery pursuant to criminal prosecutions ("actions civiles"). Indeed, almost no cases outside of the ATS context involve a private cause of action to enforce universal jurisdiction norms. The only such case cited, involving a Palestinian doctor recovering damages in a Dutch court for injuries suffered in Libya, still needed to be "sufficiently connected" to the Dutch court. See id. at 25 n.70. 
rights. Harold Koh, for instance, cited ATS litigation as a leading example of how international legal norms can be developed and strengthened through domestic and nonstate actors. ${ }^{25}$

But the ATS was not without critics. The first substantial dissenting note was registered by Judge Robert Bork, whose concurring opinion in Tel-Oren v. Libyan Arab Republic ${ }^{26}$ set in motion what I will call the separation of powers critique of the ATS. In Tel-Oren, Bork held that the ATS was merely a jurisdictional statute and that it did not authorize courts to create a private cause of action. ${ }^{27}$ Hence, no claims could be brought under the ATS itself unless or until Congress created specific causes of action. To find otherwise, Bork opined, would raise "grave separation of powers problems." 28

Bork did not challenge the significance of international law in the domestic legal system. Indeed, he conducted a lengthy investigation of international law sources to determine its applicability to the case. Rather, his criticism is based on the principle that "the conduct of the foreign relations of our Government is committed by the Constitution to the Executive and Legislative- 'the political'-Departments." ${ }^{29}$ Under Bork's approach, the decision to recognize a cause of action under international law would be reserved for Congress.

Bork's separation of powers critique did not win much support either in other courts or among scholars. ${ }^{30}$ In the late $1990 \mathrm{~s}$, academics became more interested in a similar but distinct objection to ATS lawsuits that questioned the federal status of customary international law. ${ }^{31}$ Still, it was Bork's separation of powers critique that remained the main vehicle for challenging the ATS in court. For instance, in the Supreme Court's first extended analysis of the ATS in Sosa, both the defendants and the U.S. government as amicus curiae adopted Bork's argument that the ATS did not create a cause of action and that to hold otherwise would threaten separation of powers.

Although the Sosa Court recognized the force of this separation of powers critique, it decided to leave the "door . . . ajar" for limited federal court activity in the administration of the ATS. ${ }^{32}$ Indeed, the justices were sufficiently sensitive to Bork's critique that they instructed lower courts to adopt prudential considerations to limit separation-of-powers conflicts. Such prudential considerations included giving weight to executive branch views on ATS cases as well as limiting the types of causes of action that federal courts could recognize. Breyer's invocation of universal jurisdiction in Sosa was also likely intended as a response to separation of powers concerns since foreign nations would be less likely to object to U.S. enforcement of legal norms of universal concern.

${ }^{25}$ See, e.g., Harold Hongju Koh, How Is International Human Rights Law Enforced?, 74 IND. L.J. 1397, 1414 (1999) (describing how Filártiga and subsequent ATS cases helped build support for ban on torture); see also AnneMarie Burley, The Alien Tort Statute and the Judiciary Act of 1789: A Badge of Honor, 83 AJIL 461, 489-93 (1989) (defending the use of ATS litigation to vindicate broader abstract norms).

${ }^{26}$ Tel-Oren v. Libyan Arab Republic, 726 F.2d 774 (D.C. Cir. 1984).

${ }^{27}$ Id. at 799 (Bork, J., concurring).

${ }^{28} \mathrm{Id}$. at 805 .

${ }^{29} I d$. at 801 (quoting Oetjen v. Central Leather Co., 246 U.S. 297, 302 (1918)).

${ }^{30}$ See, e.g., Burley, supra note 25, at 469 (criticizing Bork's approach); Forti v. Suarez-Mason, 672 F.Supp. 1531, 1539 (N.D. Cal. 1987) (rejecting Bork's approach in Tel-Oren and citing contrary authority).

31 See, e.g., Curtis A. Bradley \& Jack L. Goldsmith, Customary International Law as Federal Common Law: A Critique of the Modern Position, 110 HARV. L. REV. 815 (1997); A. M. Weisburd, State Courts, Federal Courts, and International Cases, 20 YALE J. INT'L L. 1, 38-44 (1995); see also Michael D. Ramsey, International Law as Nonpreemptive Federal Law, 42 VA. J. INT'L L. 555 (2002).

${ }^{32}$ Sosa v. Alvarez-Machain, 542 U.S. 692, 729 (2004). 
It is therefore not surprising that, when the Supreme Court returned to the ATS in Kiobel, separation of powers concerns were again front and center. Both of the Court's main opinions recognized the endemic separation of powers concerns raised by ATS cases. For instance, as Roberts explained in his opinion for the Court, "[T] he danger of unwarranted judicial interference in the conduct of foreign policy is magnified in the context of the ATS, because the question is not what Congress has done but instead what courts may do." ${ }^{33}$ Breyer recognized the need to "minimize international friction" caused by ATS lawsuits. ${ }^{34}$ The main difference with Roberts was Breyer's confidence that existing prudential doctrines and international law notions of jurisdiction could accomplish this goal. It is noteworthy that Breyer limited ATS cases to those involving "distinct American interests," even though international law imposes no such requirement and the sources that he cites seem to support a universal jurisdiction approach.

In my view, Breyer's surprising retreat from universal jurisdiction reflects his view that federal courts applying a broad notion of universal jurisdiction would raise too many "international friction[s]" to be consistent with the basic separation of powers concerns first raised by Bork and later recognized by the Sosa Court. Because Breyer does not offer a textual, a historical, or even a policy explanation for his shift, the concern over separation of powers embedded in the avoidance of "international friction[s]" seems the most plausible rationale.

\section{Conclusion}

As John Yoo and I have argued elsewhere, this concern about separation of powers has a functional as well as formalist basis. ${ }^{35}$ While federal courts have superior institutional competence in some areas, this competence is unlikely to include when to invoke U.S. power over foreign government actions and policies overseas. As Kiobel itself illustrates, federal courts vindicating purported international norms still sparked opposition from foreign governments like the United Kingdom and the Netherlands as well as the U.S. government itself. ${ }^{36}$ Should the "international friction" with these nations (as well as Nigeria) be overcome by universal norms, or should it be deferred to political or diplomatic measures? Kiobel leaves the resolution of this question to Congress, which is likely to have superior informational and technical expertise on how to make this determination.

While the Kiobel Court did not explicitly embrace our functional framework, its conclusions conform to our recommendations. Both the Roberts and Breyer opinions in Kiobel seem to assume that Congress has the primary, or even exclusive, responsibility to determine how and whether the United States will invoke universal jurisdiction under international law.

${ }^{33}$ Kiobel v. Royal Dutch Petroleum Co., 133 S.Ct. 1659, 1664 (2013) (emphasis added).

${ }^{34}$ Id. at 1674 (Breyer, J., concurring).

${ }^{35}$ Julian Ku \& John Yoo, Beyond Formalism in Foreign Affairs: A Functional Approach to the Alien Tort Statute, 2004 SUP. CT. REV. 153. We extend and develop this argument further in TAMING GLOBALIZATION: INTERNATIONAL LAW, THE U.S. CONSTITUTION, AND THE NEW WORLD ORDER 178-97 (2012), where we argue that privileging functional competence is a practical way to manage the collision of international and domestic law norms.

${ }^{36}$ See Supplemental Brief of the Governments of the Kingdom of the Netherlands and the United Kingdom of Great Britain and Northern Ireland as Amici Curiae in Support of Neither Party, Kiobel v. Royal Dutch Petroleum Co., 133 S.Ct. 1659 (2013) (No. 10-1491) (arguing against the applicability of the ATS overseas); Brief of the United States as Amicus Curiae in Support of Petitioners, Kiobel v. Royal Dutch Petroleum Co., 133 S.Ct. 1659 (2013) (No. 10-1491). 
This conclusion does not mean that debates over the ATS are completely resolved. But one big debate is over. The suggestions by scholars and courts that the ATS should be interpreted to reach the limits of universal jurisdiction under international law have been unanimously rejected. And the basis for their rejection indicates that the separation of powers critique of the ATS will likely dominate future debates about the ATS.

\section{KIOBEL AND THE WEAKENING OF PRECEDENT:}

\section{A LONG WALK FOR A SHORT DRINK}

\section{By Ralph G. Steinhardt*}

Kiobel v. Royal Dutch Petroleum Co. ${ }^{1}$ marks the second time in nine years that the Supreme Court has ruled unanimously that the Alien Tort Statute (ATS) ${ }^{2}$ does not provide jurisdiction in a high-profile human rights case, a sequence that might suggest an end to the gilded age of human rights litigation that began with Filártiga $v$. Peña-Irala. ${ }^{3}$ On closer analysis, however, Kiobel, like Sosa v. Alvarez-Machain before it, ${ }^{4}$ adopts a rhetoric of caution without foreclosing litigation that fits the Filártiga model. To the contrary, Sosa and Kiobel invite considerably more ATS litigation than they resolve or bar and therefore confirm Justice Antonin Scalia's memorable encapsulation of the Court's "Never Say Never Jurisprudence." All four of the opinions in Kiobel confirm that multiple significant issues remain for future resolution, but it is unrealistic to expect answers on the basis of the Court's decision because what is law in Kiobel isn't clear and what is clear in Kiobel isn't law.

What law there is-and specifically the holding that the presumption against extraterritoriality requires the dismissal of Kiobel's action against Royal Dutch Petroleum-actually creates an unprecedented and ill-defined presumption that has nothing but idiom in common with the traditional presumption as articulated by the Court in Foley Bros. Inc. v. Filardo ${ }^{6}$ and Morrison v. National Australia Bank Ltd. 'Although these "presumption precedents" drive the majority opinion, Kiobel is the first time that the presumption against extraterritoriality has been applied to a purely jurisdictional statute, ${ }^{8}$ as distinct from substantive statutes

* Arthur Selwyn Miller Professor of Law, The George Washington University Law School. The author was cocounsel for the respondent in the Sosa litigation and, with Arin Brenner, represented a group of international law scholars appearing as amicus curiae in support of the plaintiffs/petitioners in the Kiobel litigation.

${ }^{1}$ Kiobel v. Royal Dutch Petroleum Co., 133 S.Ct. 1659 (2013).

228 U.S.C. $\$ 1350$ [hereinafter ATS].

${ }^{3}$ Filártiga v. Peña-Irala, 630 F.2d 876 (2d Cir. 1980). Filártiga established that the ATS could be used to advance certain human rights claims in U.S. courts, even if the abuse occurred abroad and involved exclusively non-American citizens, so long as the defendant was within the personal jurisdiction of the court.

${ }^{4}$ Sosa v. Alvarez-Machain, 542 U.S. 692 (2004).

${ }^{5}$ Id. at 750 (Scalia, J., concurring) ("In today's latest victory for its Never Say Never Jurisprudence, the Court ignores its own conclusion that the ATS provides only jurisdiction, wags a finger at the lower courts for going too far, and then-repeating the same formula the ambitious lower courts themselves have used-invites them to try again.").

${ }^{6}$ Foley Bros. Inc. v. Filardo, 336 U.S. 281 (1949).

7 Morrison v. Nat'l Austl. Bank Ltd., 130 S.Ct. 2869 (2010).

${ }^{8}$ Sosa, 542 U.S. at 724; see also id. at 729 ("All Members of the Court agree that $\$ 1350$ is only jurisdictional."). 